\title{
Abbreviations and Technical Notes on Selected Sources
}

$\mathrm{AH}$

$C Z G B$

DFZZ

Dissertation

GCIC

GCIM

GX

$H B M C L B$ anjuan hao. Subdivider for files in Second Historical Archives, Nanjing.

Shandong caizheng gongbao.

Dongfang zazhi.

Pomeranz, Kenneth. "The Making of a Hinterland: State, Society, and Economy in Inland North China, 1900-1937." Ph.D. dissertation, Yale University, 1988.

Freeman, John Ripley. Grand Canal Investigations. Typescript, 1921; version held at library of Cornell University.

Freeman, John Ripley. Grand Canal Investigations. Typescript, 1921; version held at library of University of Michigan.

Guangxu reign (1875-1908).

Hebei mianchan lu bao. Readers may be puzzled to see a number of points concerning events in Shandong supported by references to this Hebei journal; these pages come from the magazine's "cotton news from other provinces" section, which emphasized Shandong events. 
$H H$

$H W J B$

HWTK

JD

$J S G B$

$J S Y K$

LFZZ

$\mathrm{NCH}$

NSGB

$\mathrm{NYHH}$

OEI

QYHK
Shulibu, Huang He shuili weiyuanhui. Huang He shuili shi shuyao (Outline of the history of Yellow River water conservancy). Beijing: Shuili dianli chubanshe, 1984.

Hewu jibao. This magazine also had a slightly irregular publishing schedule, and not all the issues I read had their covers; individual government orders reprinted in the magazine are usually dated, but the longer reports sometimes are not.

Shandong hewu tekan.

jiguan daihao. Reference number for files in Second Historical Archives, Nanjing.

Shandong jianshe gongbao.

Shandong jianshe yuekan.

Junjichu lufu zouzhe. Grand Council archival collection at First Historical Archives, Beijing.

North China Herald.

Nong shang gongbao.

Shandong Nan Yun Hu He su jun shiyi zhoubanchu. Diyijie baogao (Shandong Canal and Lake Dredging and Restoration Board, first report). Jinan(?), 1915.

Shandong Office to Encourage Industry (Quanyesuo).

Shandong quanye huikan. This magazine had a slightly irregular publishing schedule, and covers were missing from many of the issues used, but in almost all cases, the exact publication date was verifiable; where this was not the case, publication dates could at least be fixed within one month.

QZ Second Historical Archives, Nanjing. 


\begin{tabular}{|c|c|}
\hline RO & Shandong Reconstruction Office (Jiansheju). \\
\hline SDXZJSSYQGB & $\begin{array}{l}\text { Shandong sheng xian zheng jianshe shiyanqu } \\
\text { gongbao. }\end{array}$ \\
\hline$S D Z Z$ & Shandong zazhi. \\
\hline SS & $\begin{array}{l}\text { Tōa Dobunkai, Shina Shōbetsu Zenshi (The } \\
\text { provinces of China). Vol. 4: Shandong. Tokyo: } \\
\text { Tōa Dobunkai 1918. }\end{array}$ \\
\hline SSYZ & $\begin{array}{l}\text { Zhongguo shiyebu, guoji maoyiju. Zhongguo } \\
\text { shiye zhi, Shandong sheng (Industrial gazetteer } \\
\text { of China, Shandong province). } 1934 .\end{array}$ \\
\hline THS & $\begin{array}{l}\text { Chintao Shubigun Minseibu Tetsudōbu. Tō- } \\
\text { hoku Santō (Bokkai Santō Engan Shokō Iken } \\
\text { Chïfü Kan Toshi) (Northeast Shandong [all } \\
\text { ports on Shandong's Bohai coast, and cities be- } \\
\text { tween Wei Xian and Yantai]). Chösa Hōkoku } \\
\text { Sho (Chōsa Shiryō 17) (Research report [re- } \\
\text { search materials no. 17]). Qingdao: Chintao } \\
\text { Shubigan Minseibu Tetsudōbu, 1919. }\end{array}$ \\
\hline$X C J S X K$ & $\begin{array}{l}\text { Xiangcun jianshe xunkan/Xiangcun jianshe } \\
\text { banyuekan. Magazine changed from every ten } \\
\text { days to every two weeks in 1935, and name } \\
\text { changed accordingly, but numbering remained } \\
\text { consecutive. Because of missing covers of many } \\
\text { issues of XCJSXK and the magazine's slightly } \\
\text { irregular publication schedule, the exact day of } \\
\text { publication for issues was often impossible to } \\
\text { fix; however, the month of publication usually } \\
\text { could be easily confirmed. }\end{array}$ \\
\hline $\mathrm{XT}$ & Xuantong reign (1909-12). \\
\hline YRO & Shandong Yellow River Office (Hewuju). \\
\hline
\end{tabular}


